\title{
SCHOENOMYZA HALIDAY, REDESCRIPTION OF THE GENUS AND DESCRIPTION OF A NEW SPECIES FROM ECUADOR (DIPTERA, MUSCIDAE)
}

\author{
Márcia Souto Couri ${ }^{1}$
}

\begin{abstract}
Redescription of Schoenomyza Haliday, 1833 and the description of S. napensis, sp.n. from Napo Province, Ecuador are presented. Morphology of the terminalia are described and illustrated.

KEY-WORDS. Diptera, Muscidae, Schoenomyza, S. napensis sp.n., taxonomy
\end{abstract}

Schoenomyza Haliday, 1833 has a wide geographical distribution, being mostly represented in South America, with 17 known species (CARVALHO et. al. 1993), the majority of them described by MALLOCH $(1918,1934)$.

The known male terminalia of some Coenosiini are very typical as they have a tube-like hypandrium (see also CoURI, 1995). The male terminalia of four North American species of Schoenomyza are well illustrated in HuckeTT (1934).

The aim of this paper is to redescribe the genus with comments on its systematic position among the Muscidae and describe a new species, S. napensis, sp.n.

\section{Schoenomyza Haliday, 1833}

Schoenomyza Haliday, 1833: 166 (description). - Wulp, 1897: 346 (difference from Coenosia). Aldrich, 1905 (catalogue), - Stein, 1911: 217 (key to species). - Malloch, 1918: 288 (comments, key to species). - Stein, 1919:156 (catalogue). - Huckett, 1934: 59 (key to genus), 105 (comments and generic diagnosis), 106 (key to species). - Malloch, 1934: 210 (key), 262 (considerations), 262-264 (key to species). - Sèguy, 1937: 189 (key to genus). - Snyder, 1957: 448 (citation). Hennig, 1965: 68 (comments). - Pont, 1972: 39 (catalogue). - Couri \& Lopes, 1985: 593 (key). - Carvalho et. al., 1993: 133 (catalogue).

Type-species: Ochtiphila litorella Fallén, 1823 (=Sciomyza fasciata Meigen, 1830).

Diagnosis. Male dichoptic; frons very large, about $1 / 3$ of head width (Fig. 1); antenna short, arista with very small cilia; palpus long, slender with slightly clubbed apex. Pre-alar bristle absent; scutellum bare below and laterally; prosternum bare; proepisternals 2, propleurals 2 upwards directed, posterior one about 2.5 times the length of the anterior; katepisternals $1: 1: 1$, forming an equilateral triangle; post sternum developed; both calypters small, upper one roundish and lower one tongue-like, hardly projecting beyond the upper one; dorsocentrals $1: 3$;

1) Departamento de Entomologia, Museu Nacional. Quinta da Boa Vista, São Cristóvão , 20940-040 Rio de Janeiro, Rio de Janeiro, Brasil. CNPq fellow. 
wings with bare veins; veins $\mathrm{R}_{4+5}$ and $\mathrm{M}_{1+2}$ parallel at apex. Mid tibia at anteroventral surface with a strong bristle at middle. Hind tibia at anteroventral surface with two bristles at middle $1 / 3$, anterodorsal surface with two bristles at middle $1 / 3$, inserted a little above from the anteroventral ones and longer than those; dorsal surface with a long bristle at apical 1/3; anterior surface with two apical bristles. Sternite I bare. Male: sternite V with few bristles on disk (Fig. 2); cercal plate large (Fig. 3); hypandrium tube-like, aedeagus apodem long, surpassing posterior margim of hypandrium (Fig. 4). Female: proboscis with palpi long (Fig. 5); ovipositor long with microtrichia in all segments (Figs 6-7).

Comments. In MALLOCH's (1934) key, Schoenomyza is separated by the small lower calypter, the disposition of the bristles at apex of hind tibia, dorsocentral bristles 1:3 and finally it was separated by elimination, by the absence of a posterodorsal bristle at hind tibia. With this definition, where he gave too much weigth to the small lower calypter resulted, for instance, in the inclusion of $S$. armipes and $S$. tarsalis in this genus. Both species were described by MALLOCH (1934) and probably belong to Coenosia, as they have the typical hind tibia bristling of this genus. The types should be examined to confirm this. HUCKET's (1934) concept of Schoenomyza, includes one bristle at anteroventral surface of mid tibia. SNYDER (1957) agreed with MALLOCH (1934) but disagreed with HUCKETT (1934). He described two new species - S. neobiseriata and $S$. willinki which also probably belong to Coenosia. For these two species, it is made the same comment as above; only the examination of the type will decide this. To make Schoenomyza diagnosis more consistent, it is included the typical bristling at hind tibia was included.

The disposition of katepisternal bristles in an equilateral triangle and the presence of microtrichiae at ovipositor places this genus among the Coenosiinae, Coenosiini (sensu CARVALHO 1989).

\section{Schoenomyza napensis, sp.n.}

\section{Figs 1-7}

Holotype male. Label: "ECU: Napo Prov., above / Papallacta, paramo \& / elfin forest, 4000m. / ii. 1983, M. Sharkey / \& L. Masner"; "Holotipo" [red label] / Schoenomyza napensis Couri [handwritting]/M.S. Couri det. (MNRJ). Specimen glued at pin at left side. (MNRJ). In good conditions, wings a little damaged at tip. Terminalia in a micro-vial in glycerin.

Paratypes. Seventeen males and five females. Same label as holotype; "Paratypo" [green label]/Shoenomyza napensis Couri [handwritting]/M.S. Couri det. (MNRJ). One female with head and another female with abdomen in a micro-vial in glycerin.

Diagnosis. Male frons brown superiorly and strongly silvery pollinose inferiorly as in figure 1; face and parafacial chocolate brown, gena yellow dusted. Female with colors of frons and face much more paler than in male; frons grey inferiorly and brown superiorly, face and gena yellow dusted. Wing with a very faint brown spot at $r-m$ cross-vein. Legs dark brown with femoro-tibial joints 
yelowish. Hind femur at dorsal surface with a row of 4-5 sparse bristles, anteroventral surface with sparse bristles at basal half, and with one bristle at apical $1 / 3$.

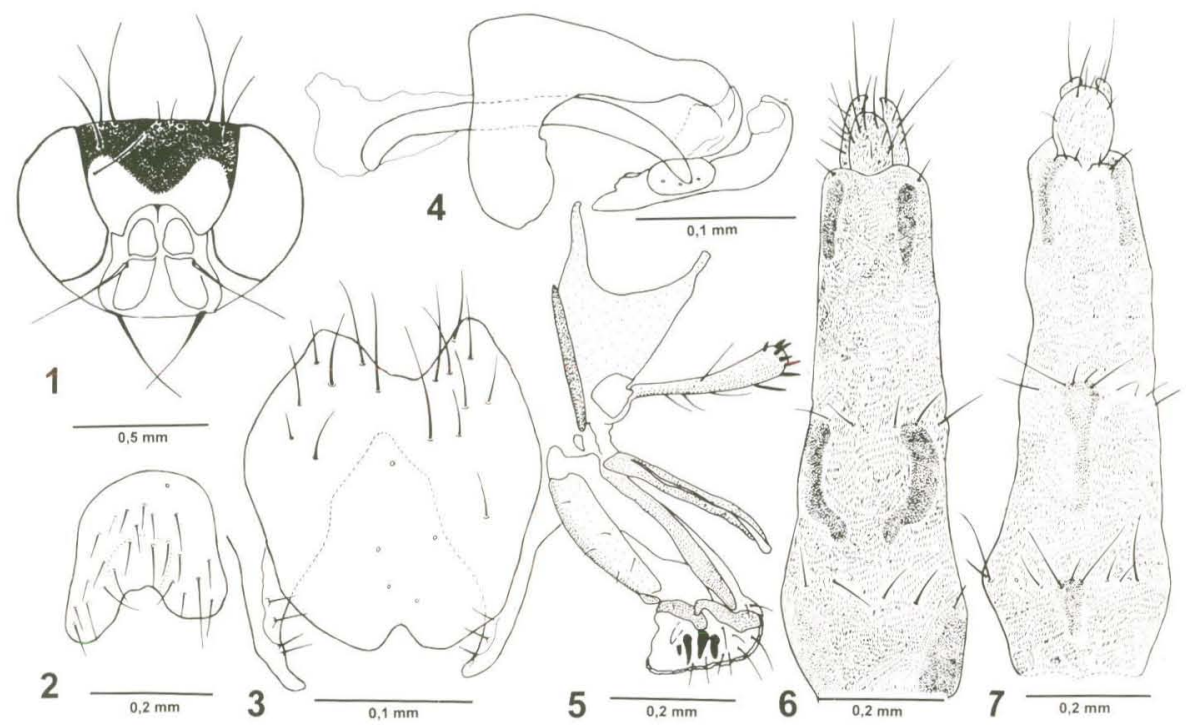

Figs 1-7. Schoenomyza napensis, sp.n.. (1-4) Male. (1) Head; (2) sternite V; (3) cercal plate and surstyli; (4) aedeagus, lateral view. (5-7) Female. (5) Proboscis, lateral view; (6) ovipositor, dorsal view; (7) ovipositor, ventral view.

Coloration. Frons brown superiorly and strongly silvery pollinose inferiorly as in figure 1. Face and parafacial chocolate brown, gena yellow dusted. Antenna brown, strongly silvery pollinose. Arista and palpus brown. Mesonotum brown with pollinose grey areas. Pleurae of same color of mesonotum. Calypter whitish. Halter yellow. Wing with a very faint brown spot at $r-m$ cross-vein. Legs dark brown with femoro-tibial joints yelowish. Abdomen greyish pollinose, with lateral dark-brown triangular spots in center of tergites II and III; and sub-triangular lateral spots in tergites IV and $\mathrm{V}$.

Male. Body length: $3.0-3.2 \mathrm{~mm}$; wing: $2.5-2.8 \mathrm{~mm}$.

Head. (Fig. 1). Eyes separated, at anterior ocelli level, by a space about $0.48-0.50$ of head width. Inner facets near antenna larger than the outer ones. Frons with two pairs of frontal bristles, the upper one backwards directed. Antenna short with flagellomere about 1.4-1.6 the length of pedicel.

Thorax. Acrostichal hairs biseriated on their entire extent; humerous with two bristles, one longer, about 2.5 times the length of the other; presuturals 1 ; supralar 1; post-supralar 2. Notopleuron with two bristles, the anterior one about 1.8 times the length of the posterior. Scutellum with a basal lateral and an apical pair of strong bristles. Fore femur at posterodorsal and posteroventral surfaces 
with a row of bristles; ventral surface with about five sparse bristles. Fore tibia at posteroventral and posterodorsal surfaces with a sub-median bristle, posterior surface with two pre-apical bristles. Mid femur at ventral surface with sparse and fine bristles at basal half. Mid tibia at anterodorsal surface with a submedian bristle; posterior surface with a median bristle; dorsal surface with one bristle at apical 1/3; anteroventral, ventral and posteroventral surfaces with an apical bristle. Mid tibia at ventral surface with a median bristle, dorsal surface with a submedian bristle, posterior surface with a short median bristle, anteroventral and posteroventral with a strong apical bristle. Hind femur at dorsal surface with a row of 4-5 sparse bristles, anteroventral surface with sparse bristles at basal half, and with one bristle at apical $1 / 3$. Hind tibia at anteroventral and anterodorsal surfaces with two bristles at middle $1 / 3$, and one at apical $1 / 3$; dorsal surface with a long bristle at apical $1 / 3$, ventral surface with an apical bristle.

Abdomen. Tergites I-IV with a delicate pair of lateral bristles, tergite $\mathrm{V}$ with delicate sparse bristles at disk and margin. Sternite $V$ with few bristles on disk (Fig. 2).

Terminalia. Cercal plate large, surstyli straigth (Fig. 3); hypandrium tube-like, aedeagus apodem long, surpassing posterior margin of hypandrium (Fig. $4)$.

Female. Differs from male in following: colors of frons and face much paler than in male; frons grey inferiorly and brown superiorly, face and gena yellow dusted, antenna not silvery pollinose, except at apex of pedicel.

Terminalia. Ovipositor long with microtrichia in all segments; cerci long surpassing hypoproct (Figs 6-7).

Comments. This species was collected at $4.000 \mathrm{~m}$, higher than all other known Schoenomyza. In MALLoch's (1934: 262) key, this species approaches couplet 5 , differing from the other species mainly on the color of head and legs, chaetotaxy of posterior tibia and dispositions of acrostichal bristles.

ACKNOWLEDGMENTS. I am grateful to Dr. Stephen Marshall (University of Guelph, Ontario, Canada) for the donnation of specimens to Museu Nacional, Rio de Janeiro and also to "Fundação Universitária José Bonifácio" (Proc. 5295-7) for the financial support.

\section{REFERENCES}

ALDRICH, J.M. 1905. A catalogue of North American Diptera (or two-winged flies). Smithson. misc. Colect. 1444: 1-680.

CARvalho, C.J.B. DE. 1989. Classificação de Muscidae (Diptera): uma proposta através da análise cladística. Revta bras. Zool.6 (4): 627-648.

Carvalho, C.J.B. DE; M.S. Couri; A.C. Pont; D. Pamplona \& S.M. Lopes. 1993. Part II. Muscidae. In: C.J.B. Carvalho DE. (Ed.). A Catalogue of the Fanniidae and Muscidae (Diptera) of the Neotropical Region. São Paulo, Sociedade Brasileira de Entomologia, 201p.

COURI, M.S. (1995). Contribution to the knowledge of Reynoldsia Malloch 
(Insecta: Diptera: Muscidae). Proc. Biol. Soc. Wash. 108 (2): 281-291.

COURI, M.S. \& S.M. LoPES. 1985. Neotropical genera of Coenosiinae - nomenclatural notes and key to the identification (Diptera, Muscidae). Rev. Brasil. Biol. 45 (4): 589-595.

Haliday, A.H. 1833. Catalogue of the Diptera occuring about Holywood in Dowmshire. Ent. Mag. 1: 147-180.

HENNIG, W. 1965. Vorarbeiten zu einem phylogenetischen System der Muscidae (Diptera, Cyclorrapha). Stuttg. Beitr. Naturk. 141: 1-100.

HucketT, H. 1934. A revision of the North American species belonging to genus Coenosia Meigen and related genera (Diptera: Muscidae). Part I. The subgenera Neodexiopsis, Coenosia, Hoplogaster and related genera Allognata,

Bithoracochaeta and Schoenomyza. Trans. Amer. Ent. Soc. 60: 57-119.

Malloch, J.R. 1918. Diptera from South western United States. Paper IV. Anthomyidae. Trans. Amer. Ent. Soc. 44: 263-319.

1934. Diptera of Patagonia and South Chile. 7. Muscidae (2): 171-346. London, BM(NH).

Pont, A.C. 1972. A Catalogue of the Diptera of the America South of the United States. 97. Family Muscidae. São Paulo, Museu de Zoologia, Universidade de São Paulo, 111 p.

SÉGuY, E. 1937. Diptera, Family Muscidae. In: P. Wytsman. Genera Insectorum. 205: 1-604.

SNYDER, F.M. 1957. Notes and descriptions of some neotropical Muscidae (Diptera). Bull. Amer. Mus. nat. Hist. 113: 437-490.

STEIN, P. 1911. Die von Schnuse in Südamerika gefangenem Anthomyiden. Arch. Naturgesch. 77 (1): 61-1898.

1919. Die Anthomyidengattungen der Welt, analytisch bearbeitet, nebst einem kritisch-systematischen Verzeichnis aller aussereuropäischen Arten. Arch. Naturgesch. 83 A 1: 85-178 [1917].

Wulp, F.M. VAN DER. 1897. Group Anthomyiinae [Concl.] In: F. D. GOdMAN \& O. SAlviN (Eds). Biologia Centrali-Americana. Zoologia-InsectaDiptera 2 (Part 137): 345-360, London. 